\title{
Code-Switching and Mixing in Communication -A Study on Language Contact in Indian Media
}

\author{
Chetia Barnali \\ $\mathrm{PhD}$, Assistant Professor \\ Indian Institute of Information Technolgy, Vadodara, India \\ bchetia03@gmail.com
}

\begin{abstract}
In India, language is the key instrument by which we assimilate the culture. And it is a major means of identifying a set of people, nation or country. Hinglish, a portmanteau of "Hindi" and "English", is a hybrid of English and South Asian languages. It is a code-switching and mixing variety of these languages whereby they are freely interchanged within a sentence or between sentences. In a multilingual country like India code-mixing and switching has become a norm rather than a deviation. It is also noticed that linguists use the term code-mixing and switching interchangeably, especially in case of formal studies on syntax and morphology. Language contact is considered to be an important phenomenon, especially in a multilingual society like India. While the name is based on the Hindi language, it does not refer exclusively to Hindi, but is used in India, with English words blending with Punjabi, Urdu and Hindi. With the advent of modern technology, and the availability of popular media in finger tips, from a toddler to a nonagenerian, the very concept of language, culture and communication has undergone a huge change. Hinglish and code-mixing and switching has crept its way into advertisements, TV shows, and Bollywood movies as well as the corridors of corporate and political power in India. This paper is an empirical study of code mixed and switched utterances in the form of songs, ad taglines and jingles in Indian media which came into existence as a by product of modern technology and changed the definition of communication in Indian media. And this paper further discusses the scope of Hinglish as the lingua franca for not only the upper-class urban Indians, but also semi-urban and rural centers of the Hindi-speaking states of India
\end{abstract}


where modern technology in the form of television, radio, mobile phones, internet (social networking sites) etc. has become an indispensable part of their life.

KEY WORDS: Code-mixing/switching, Technology, Hinglish, Communication, Language Contact, Media

"A crucial factor in language change is adults abbreviating the machinery of a language, along a gradient of degree according to typological distance between native language(s) and acquired language, demographic proportion of learners to native speakers, and the extent to which the native version of the acquired language remains available in the genesis context over time."

McWhorter (2005:265)

Language is a social phenomenon. It is through language that day-to-day interactions and interpersonal relations are possible. Language shapes the society and culture. Crystal $(1985,262)$ observes that of all the means of communication, language is the most frequently used and developed. Languages have always been influencing each other in certain ways. Normally, this interaction is reflected in language convergence, borrowing and replacement. It may also lead to the emergence of hybrid languages, such as pidgins, creoles, and other mixed languages. In Sociolinguistics, this branch of study is called language contact. Language contact is considered to be an important phenomenon, especially in a multilingual society. Many scholars have discussed sociolinguistics and have come up with several definitions based on their individual perspectives. Hudson $(2001,4)$ defines sociolinguistics as the study of language in relation to the society. It is the study of language as it affects and is being affected by social relations; it is also the study of language and linguistic behaviour as influenced by social and cultural factors. Fishman $(1972,9)$ defines sociolinguistics as the study of the characteristics of language varieties, the characteristics of their functions, and the characteristics of their speakers as these three constantly interact, change and change one another within a speech community.

Multilingualism has always been common in the human history. In today's world of globalization, most of the people are multilingual, and not by volition but by force. Therefore, studying the aspects of language contact and its influence is a significant matter. This paper is an attempt to assess the possible outcome of such influence in the Indian media.

\section{Code-mixing and Code-switching}

Fishman $(1980,255)$ explains the domains of linguistic choice as the "classes of situations" suggesting that for each situation there is a variety that is preferred 
which can be observed directly through occurrences of code-switching. In bilingual communities code-mixing and code-switching are widespread phenomena where speakers use their native tongue (L1) and their second language (L2) in different domains. The term 'code-switching' refers to the alternate use of two or more languages in an extended stretch of discourse, where the switch takes place at sentence or clause boundaries. However, the term code-mixing refers to the mixing of two or more languages or language varieties in speech. A code may be a language or a variety or style of a language; the term code-mixing emphasizes hybridization, and the term code-switching emphasizes movement from one language to another. It is noticed that in the formal studies of syntax and morphology, linguists use the term code-mixing and switching interchangeably.

Several scholars have attempted to define code-switching and code-mixing. Poplack $(1980,586)$ opines that code-switches will tend to occur at points in discourse where juxtaposition of L1 and L2 elements does not violate a syntactic rule of either language, i.e., at points around which the surface structures of the two languages map onto each other. According to this simple constraint, a switch is inhibited from occurring within a constituent generated by a rule from one language which is not shared by the other. Code-mixing is also called intra-sentential code switching or intra-sentential codealteration and this happens when speakers use two or more languages below clause level within one social situation. Patterns of code-switching are found to be different from one another because of several distinct processes such as 'insertion,',alteration' and 'congruent lexicalization'. These three processes correspond to dominant models, and approaches (Muysken 2000,3).

Maschler (1998: 125) defines code-mixing or a mixed code as "using two languages such that a third, new code emerges, in which elements from the two languages are incorporated into a structurally definable pattern." In other words, the code-mixing hypothesis states that when two code-switched languages constitute the appearance of a third code it has structural characteristics special to that new code.

In a multilingual country like India code-mixing and -switching has become a norm rather than a deviation. Hinglish, a portmanteau of "Hindi" and "English", is a hybrid of English and South Asian languages. It is a code-switching variety of these languages whereby they are freely interchanged within a sentence or between sentences. While the name is based on the Hindi language, it does not refer exclusively to Hindi, but is used in India, with English words blending with Punjabi, and Hindi. Hinglish has become the lingua franca for most upper-class Indians, especially the youth. Although this is more commonly seen in urban and semi-urban centers of the Hindi-speaking 
states of India, it is now slowly spreading into rural and remote areas of all the states via television, radio, mobile phones, internet (social networking sites) and word of mouth thereby achieving vernacular status gradually. Radio jockeys and TV anchors deliberately mix English words with stream of Hindi sentence to sound more chique and funky. There are certain words that cannot be replaced with any regional language. Certain words like train, TV, computer, mobile, and so on, do not have similar words in any other Indian language. And even if they exist they are not used in day-to-day language.

In 2016, after a span of almost five years, Airtel India has brought back their most popular humming tune 'Har Ek Friend Zaroori Hota Hain' to promote its latest product features like free international calls while roaming abroad, Airtel-to-Airtel free calls and data packs. This campaign was first released in 2011 and it was the agency's first piece of communication made for the brand. The jingle instantly connected with the youth, which was also the target of the brand. This ad by Airtel is the best example of how to deliver needs of communication, react on them and engage to Gen next. The beauty of the jingle is in the integration of simplicity and code mixed punch phrases.

Chai ke liye jaise toashota hai / Vaise har ek friend zaroori hota hai Aise har ek friend zarori hota hai / Koi subah paanch baje neend se jagaye

Koi raat ko teen baje jaan bachaye / Ek teri kadki mein sharing kare Aur tere budget mein sneak in kare / Koi nature se guest koi host hota hai Par har ek friend zaroori hota hai /Ek ghadi ghadi kaam aaye par kabhi kabhi call kare / Ek kabhi kabhi kaam aaye aur ghadi ghadi call kare

Gossip ka koi ghoomta phirta satellite / Koi sath rahe toh kar de sab alright

Koi effortless koi forced hota hai / Lekin har ek friend zaroori hota hai

Chatroom friend koi classroom friend / Koi bike pe race wala vroom vroomfriend Shopping mall wala shopping friend / Exam hall wala copying friend / Movie buddy groovie buddy / Hi buddy.... bye buddy / Joke buddy poke buddy / Gaana buddy shaana buddy / Chaddi buddy yaar buddy Kutte . kamine / Everybody... sab buddy / A to Z

Gin din ke naam bheja roast hota hai / Par har ek friend zaroori hota hai Lekin har ek friend zaroori hota hai / Guys guys principal.. principal.. principal.. la la la... la la..... / Har Friend Zaroori hai, yaar! 
There are ad jingles that are perfect examples of code-switching/mixing. One of the earliest in this genre was the milk promotion advertisement done by FCB Ulka for NDDB. This jingle still run as one of the all time favourites in the Indian ad world.

Piyo glass full doodh, dhoodh hai wonderful / Pee sakte hai roj glass full Garmi me dalo doodh me ice / Doodh bangaya very nice Piyo daily once or twice / Mil jayega tasty surprise / Doodh doodh (5 times)

Piyo glassfull doodh / Doodh hai mast in every season

Piyo doodh for healthy reason / Rahoge phir fit and fine Jiyoge past charo aur mach gaya shor / Give me more / Doodh doodh Piyo glassfull doodh / Moooo

Another such jingle is by the telecom service provider Idea. The catchy jingle as stated below, shows various people, locations and situations from all across the country and depicts how Idea customers benefit from its pan-India network. The advertisement shows Indians from around the country, with varied cultural backgrounds, connecting as one big happy family humming one happy song - "Honey Bunny". Though, there appears to be no effort in espousing any deep message in the advertisement it is nevertheless happy, catchy and appears to influence and persuade the target audience by sheer use of endearing and funny code mixing patterns.

You're my pumpkin, pumpkin, hello honey bunny / I'm your dumpklin, dumpklin, hello honey bunny / Feeling something something, hello honey bunny, honey bunny / Toko ... toko ...

You're my pumpkin, pumpkin, hello honey bunny / I'm your dumpklin, dumpklin, hello honey bunny / Feeling something something, hello honey bunny, honey bunny / Toko ... toko ...

How many times lady love had given me missed calls / What to tell you lazy luck no battery at all / Idhar udhar heart pouchhing like a ping pong ball ballballballballball / Tringtringtringtringtringtring ... hello honey bunny / Feeling someting something, hello honey bunny / You're my pumpkin, pumpkin, hello honey bunny, honey bunny / Toko ... toko ...

$$
\text { / La... La... }
$$


You've been such a stupid fellow that is what I thought / Making people fall in love no other work or what / Got to know him better when you enter the plot plotplotplotplotplot / Thanks to his idea, you're my honey bunny I'm your pumpkin piya, you're my honey bunny / Bole - tringtringija, you're my honey bunny, honey bunny / Toko . . toko ...

I'm your pumpkin, pumpkin, hello honey bunny / I'm your dumplin, dumplin, hello honey bunny / Feeling something something, hello honey bunny. honey bunny Toko ... toko ...

Tringtringtringtringtringtring hello honey bunny / Feeling something something, hello honey bunny, honey bunny / You're my pumpkin, pumpkin, hello honey bunny, honey bunny / Toko ... toko ...

Yet another ad jingle, which is a perfect example of code-switching/mixing, is the Coca-Cola advertisement jingle. It goes with the tagline Believe in a better tomorrow. The ad has been designed to encourage people to not only recognize that there are reasons to believe in a better world, but to seek these reasons out, talk about them and even create them! The campaign focused on inspiring optimism and encouraging positive action. A song sung by a choir of young people singing actually makes one believe that there are many reasons to believe in a better tomorrow.

Ummeedon Waali Dhoop / Sunshine Waali Aasha

Rone Ki Wajah Kamm Hai Hansne Ke Bahane Jyada Zidd Hai Muskurayenge / Khush Rehne Ka Hai Waada

Umeed Wali Dhoop / Sunshine Waali Asha

Tum dil se agar puchhoge / Woh khush rehna hi chahe Jab sache mann se maango / Toh khul jaati hai raahein

Toh khul ke khusi lutaao

Ye kya aadha-aadha

Umeedon wali dhoop, Sunshine Wali asha

Umeedon wali dhoop, Sunshine Wali asha 
Code mixing as seen in Advertisement taglines

\begin{tabular}{|l|l|}
\hline PRODUCT & TAGLINES \\
\hline Coca-Cola & Thanda matlab Coca-Cola \\
\hline Pepsi & Yehi hain right choice baby \\
\hline Vicco & Vicco turmeric nahi cosmetic \\
\hline & Vicco turmeric ayurvedic cream \\
\hline Bajaj Coolers & Ekdum solid cooling \\
\hline HimaniNavratna Talc & ThandaThanda Cool Cool \\
\hline Tata Docomo & Ab aapki duniya open \\
\hline SugarfreeNatura & Live Life kuch zyada \\
\hline Ponds beauty magic & Andar se de spotless aura sirf so dino mein \\
\hline Dove & Naya Dove whitening deodorant \\
\hline Maggi Noodles & Taste bhi, Health bhi \\
\hline Tata Sky & Isko laga dala toh life zingalala \\
\hline Sprite & Bujhaye pyaas, baki all bakwas! \\
\hline 7 up & Mood ko do Lemon ka lift \\
\hline Virgin Mobile & Think Hatke \\
\hline Mirinda & $\begin{array}{l}\text { Holi hamper Jeetne ka funda } \\
\text { Ghar pe rakho Mirinda }\end{array}$ \\
\hline Nimbooz & Refreshing Nimboo paani With asli lemon juice \\
\hline Sprite & Clear hain! \& Seedhi baat. No bakwaas \\
\hline Domino's Pizza & Hungry kya? \\
\hline Lays & Pal banaye magical \\
\hline Hero Moto corp & Hum mein hain hero \\
\hline Close-Up & Kya aap Close-Up karte hain? \\
\hline Crest & Look Ma, no cavities! \\
\hline Coke & Life ho to aisi \\
\hline Lacto Calamine & Dilka confidence chehre par \\
\hline Colgate active salt & Massore swast aur taste mein mast \\
\hline Airtel Internet & Ek rupiye mein full masti \\
\hline Rasna (fruit plus) & Kabhi bhi rasna kabhi bhi energy \\
\hline Cadbury's & $\begin{array}{l}\text { Ish T20 late working ka shubharambh } \\
\text { Kuch meetha ho jaye }\end{array}$ \\
\hline & \\
\hline
\end{tabular}




\begin{tabular}{|l|l|}
\hline Domino's pizza mania & Yeh hain rishtonka time \\
\hline Pepsi & Oh yes abhi \\
\hline Tata Docomo & Network Harjagah, hamesha \\
\hline Coca Cola & Khusiyan lutaon crazy kehlaon \\
\hline Dettol soap & Ab bane har morning Goodmorning \\
\hline Colgate sensitive tooth brush & Dentist ka no.1 choice \\
\hline Fogg deodorant & Bina gas wala fogg \\
\hline Idea & What an idea sirjee! \\
\hline Bisleri 500 & Pehle apni kharido Phir kiss karo \\
\hline Cadbury's gems & Raho umarless \\
\hline Kurkure & Chai time Masti bole toh Kurkure \\
\hline Blue & At your best / Hamesha! \\
\hline
\end{tabular}

The first application of Hinglish in the form of code mixed and switched utterances was witnessed in the India under British, in the words of Ayodhya Prasad Khatri (1857-1905), a prominent Hindi poet. He wrote:

Rent Law ka gham karen ya Bill of Income Tax ka?

Kya karen apan nabiin bai sense right now-a-days.

Darkness chbaaya bua bai Hind men chaaro taraf

Naam ki bhi bai nabiin baaqi na light now-a-days.

Again, in Bollywood, Gulal (2009) was this blend of macro politics with student politics, where an apolitical new student, is involuntarily sucked into the vortex of blood, hate and violence. Piyush Mishra, as the fan of John Lennon, voice-of-conscience Rajput gifted the viewers with powerful lyrics and music that carried the narrative forward, even as they render a forceful critique of the state of the nation. The lyrics of the song 'Ranaji' come across as a classic case of code-mixing.

Haay raanaji mhaare gusse mein aaye, aiso balkhaaye

Agiya barsaaye, ghabraaye mbaaro chain jaise dur des ke tower mein ghus jaaye re airoplane

Haay raanaji mhaare gusse mein aaye, aiso balkhaaye

Agiya barsaaye, ghabraaye mbaro chain

Jaise dur des ke tower mein ghus jaaye re airoplane

Raanaji mbaare aiso gurraye, aiso tharraye 
Bhar aaye mharo nain / Jaise sare aam bhai Jaise sare aam iraak mein jaake jam gaye ancle sam Raanaji mbaare........

Sajani ko dear bole, tharre ko beer bole Maange hai englis boli, maange hai englis choli

Maange hai englis jaipuri, englis bikaaner Jaise biseleri ki botal pike ban gaye englis man Jaise biseleri ki botal pike ban gaye englis man Raanaji mbaare.......

Raanaji mbaare sautan ko ghar le aaye Puchbe tob bole friend hamaari hai haay Raanaji ne thanda chakku yuun khola Bole ke baaye thanda maane coka cola Raanaji bole goro ki basti mein hai shor raani

Haay baay moro ki basti mein chor raani Hoy boy hoy hoy moro ki basti mein chor raani Kyun ki yeb dil maange more

More rani, more rani, more rani, more rani Mhaari toh bich bajariya, haay badnaami ho gayi Mhaari tob laal chunariya saram se dhaani ho gayi

Mhaaro tob dhak dhak howe jo jo bite re Jaise har ek baat pe democracy mein lagane laga gaya band Jaise har ek baat pe democracy mein lagane laga gaya band

Jaise dur des ke tower mein ghus jaaye re airoplane Jaise sare aam iraak mein jaake jam gaye ancle sam Jaise bina baat afganistaan ka baj gaya bhaiya band Jaise bina baat afganistaan ka baj gaya bhaiya band

Jaise dur des ke tower mein ghus jaaye re airoplane ..raanaji mbaare...

With English Vinglish (2012), female director Gauri Shinde brings her own lifetime of experience into the picture. The image of the newly confident Shashi striding down a Manhattan street, a takeout coffee in hand and a trench coat belted over her sari, makes one smile days after you have left the theater. English Vinglish springs up a sweet musical surprise, a lovable and adorable innocent feeling that not only enlightens up 
senses but amuses too with its simplicity and modesty. Tall skyscrapers, slick fashionstores...that's Manhattan for the viewers! To get a kaleidoscope view of Manhattan for B-town listeners, there's a situational track titled "Manhattan", a number that sounds more like a "guide-map" to all luxuries and happenings of this urban city.

Clinton Cerejo's boyish charms and Bianca Gomes's quirky vocals exemplify it in all vivacious and boisterous loud singing modes. The striking feature is Bianca's chirpy singing in listing out all worlds' top-most fashion brands in her "twittering" voice; overall a cool rendezvous of code-mixing which succeeded in influencing and persuading the viewers.

Aadmi topi doop ki chbaap / Manhattan! manhattan! Jannat tak hai baap re baap / Manhattan! manhattan! Amber ko chboota jahan bai / Chalta firta sapna bai Pal pal chalti hain yeh raabein / Rukti kab kahan hain... Manbattan! manhattan! [new york]

Manhattan! manhattan! [new york, new york, new york] Aadmi topi doop ki chbaap / Manhattan! manhattan!

Jannat tak hai baap re baap / Khushiyon ke naye paimaane Kbwaabon ki lagi bain dukaane / Lamba-lamba sadkon par / Achrajse mulakatein

T. t.. t.. t.. to your left is prada / To your right is zara Giorgio armani, thank god it's friday / Gucci and versace / Jimmy choo, givenchy Diesel, dior, bokey pokey, gap and bloomingdale Louis vuitton.. vuitton.. vui.. vui.. vui.. / Vuitton.. vuitton.. vuitton.. vuitton.. Moschino.. chino.. chino.. k.. k.. k.. k.. / Chino..chino..chino..

Valentino... tino... tino... t.. t.. t.. t.. / Tino... tino... tino... / Dekho..

Kbushiyon ki kaana phusi

Masti me na kanjoosi / Maze kar Kudrat hui hai meharbaan... baan... baan... baan...

Saara shehar / Ajnabi si khamoshi / Saara shehar

Thandi si garm joshi / Har ek nazar

Dikbti bai tanba tanba 
Hai zuban par sab bezubaan hai / Saare sath to hai par juda bai

Sheher ko nazar ka tika to laga do...

New york.. new york.. new york.. new york.

5,6,7,8 avenues / Million billion legs and shoes / Lots of colors, dollars dollars

Sense of piddly poo / Breakfast is for all day / Straight and gay they all sway

And lexington, and madison, it's all so ooob!

Frappuccino.. chino.. chino.. chino.. / Mochaccino.. chino.. chino.. chino..

Cappuccino.. chino.. chino.. chino..

Yet another song with code-mixed and switched lyrics is witnessed in Imtiaz Ali's Tamasha (2015), a story which starts with the protagonists incognito trip to Corsica. A story about more stories on angst, passion and life. The song Heer tob badi sad hai... is composed by A.R Rahman and sung by Mika Singh and Nakash Aziz.

Heer tob badi sad / Aajkal very mad / Heer tob badi sad

Aajkal very mad / Na khaati peethi / Rona toh na mushkil

Pyar ki lu mein itni jal gayi.. / Lu mein jaana mushkil bain

Lu mein jaana mushkil bain / Heer ki haalat

Kasam Rab ki, kasam Rab ki / Kasam Rab ki..

Aaj kal very bad hai ji / Heer to badi sad hai ji / Aaj kal very mad hai ji

Heer tob badi sad hai ji / Ho ishq hain maachis dil hai diesel

Dono tange dooram door / Kaante paante ankh ankb ko

Sapne kar ke chooram choor / Haan baji padi band Heer ki

$A b$ iss band pe nache kaun / Huyi bol ti bandh bandh si

Kayi din o se hai wob bore / Log kahe ki sanki ho gayi.

Haan ya wo utter mad hai / Heer tob badi sad hai / Heer tob badi sad hai

Aaj kal very bad hai ji / Ho mann mridang baje bedhang

Udda hai rang bechare ka / Lukk mukk uppar pressure cooker

Huaa dimag kunware ka / Haan tel lagaye nai zindagi / So-so ke din kaante woh

Waqt ke munh pe gussa kar ke / Maarti rebti chante woh

Fikr mein ab tob uska dad hai / Haan mom bhi badi sad hai

Heer to very mad hai / Aaj kal very bad hai / She's still not glad hai

Na khaati peethi / Rona tob na mushkil

Pyar ki lu mein itni jal gayi / Lu mein jaana mushkil bai

Lu mein jaana mushkil hai / Heer ki haalat 
Kasam Rab ki, kasam Rab ki / Kasam Rab ki..

Aajkal very bad hai ji / Heer to badi sad bai ji

Aajkal very mad hai / Heer to badi sad bai ji

With language change, there is a change in culture too. There are foot-tapping breakup songs in Hinglish for celebrating breakups in Karan Johar's Ae Dil He Mushkil (2016), sung by Arijit Singh and Badshaah.

Breakup song, breakup song / Karde dil ki feeling strong / Saade chaar minute long Breakup song, breakup song / Break break B B.. Breakup song

Break break B B.. Breakup song / Angrezi chidiya ki khaatir / Desi dil mera tod diya Maine chbod diya / Usey chbod diya / Uski kaali kartooton ne

Uska bhaanda phod diya / Maine chhod diya / Usey chbod diya Dil pe patthar rakb ke / Munb pe makeup kar liya / Ob dil pe patthar rakb ke Munb pe makeup kar liya / Mere saiyyan ji se aaj / Maine breakup kar liya Mere saiyyan ji se aaj / Maine breakup kar liya / Subab savere utb ke maine

Ye sab kar liya / Mere saiyyan ji se aaj / Maine breakup kar liya Humko bin bataye tune / Ye kab kar liya?

Arey bumko bin bataye tune / Ye kab kar liya?

Ob tere saiyyan ji se kaahe / Tune break up kar liya / Tere saiyyan ji se kaabe Tune breakup kar liya / Subab savere uth ke maine / Ye sab kar liya Tere saiyyan ji se kaabe / Tune breakup kar liya / B b.. breakup song

Kuch din to rona dhona bumper kiya / Aur phir delete uska number kiya Aansu jo sookhe seedha parlour gayi / Parlour mein jaake shampoo jamkar kiya College ki sabeliyon se catch-up kar liya / Arey college ki sabeliyon se catch-up kar liya Jinko mill na paayi unko whatsapp kar diya / Mere saiyyan ji se aaj maine breakup kar liya / Subab savere uth ke maine ye sab kar liya

Mere saiyyan ji se aaj maine breakup kar liya

Look, baby! mujhe lagta bai ki

Jo bhi tune kiya hai wo very very right hai / Bhoot-kaal ko bhool ja ab tu

Aane wala future very very bright hai / Main hoon na baby saath tere

Party sharty honi poori night hai / Mind na karna jo thoda zyada bol doon

Kyunki banda very very tight hai / Usey phone mila aur gaali de

Photo jala ke karde raakb / Saale teri maa ki aankb!

Kalti bua jo saiyan stupid tera / Jeevit bua bai phir se cupid tera

Baasi relationship ka label hata / Duniya ko tu bai available bata 
Arey mere soye armaano ko wake up kar diya / Arey mere soye armaano ko wake up kar diya / Ke tere saiyan ji se (aaha!)

Tune breakup kar liya

Tere saiyyan ji se kaabe tune.. / O tere saiyyan ji se kaabe tune / breakup kar liya

Tere saiyyan ji se kaabe tune / breakup kar liya

B b.. Breakup song... / Karde dil ki feeling strong...

As evident from the above discussion code mixing and switching in the veil of Hinglish has crept its way into advertisements, TV shows, and Bollywood movies as well as the corridors of corporate and political power in India. Some popular movie titles which used Hinglish are Kill Dil (Kill Heart), Ek Villain (One Villain), Darr @ The Mall (Fear at the Mall), Super Nani (Super Grandma), Tanu Weds Manu (Tanu Weds Manu-no translation required), Jodi Breakers (Couple Breakers), Jab We Met (When We Met).

Over the years, Hinglish has been effectively used in Indian advertising in ad taglines, like Pepsi’s 1998 slogan Yeb Dil Maange More! (This heart demands for more!), Dominos Pizza tagline "Hungry kya" (Are you Hungry?), again the well-known hair oil brand Parachute "Gorgeous, Hamesha"(Always Gorgeous). Even "English-language" newspapers in India pepper their text with words borrowed from Hindi.

And the process is on, this trend is expanding its tentacles to the small towns and villages, resembling the British expansion in India in the eighteenth century. Hinglish has become a common household language and is used extensively, starting from texting to tweeting. These code-mixed and switched utterances have established themselves as the lingua franca for not only the upper-class urban Indians, but also semi-urban and rural centers of the Hindi-speaking states of India where modern technology in the form of television, radio, mobile phones, internet (social networking sites) etc. has become an indispensable part of their life.

It is believed that languages evolve constantly, and any language that doesn't change according to the demands of time, will not develop. The beauty of a language lies in its ability to adapt. And Hinglish has adapted well to the cross-cultural generalizations and stereotypes of the Indian subcontinent. 


\section{References}

Chatterjea, Gautham. 2005. Advertising Karma. New Delhi: Rupa and Co.

Crystal, David. 1985. Linguistics. England: Penguin Books.

Crystal, David. 2004. "Future is Hinglish, not English." The Tribune. Saturday, October 16.

Farb, P. 1973. Word Play: What Happens When People Talk. New York: Bantam.

Fishman, J. 1972. Sociolinguistics. Rowley, MA: Newbury House Fromkin.

Hornby, S. 2001. Oxford Advanced Learner's Dictionary. Oxford University Press: London. 6th Edition. 667.

Hudson, R. A. 2001. Sociolinguistics. Cambridge: Cambridge University Press.

Kazmi, N. 2009. "Gulal" Times of India. Retrieved 2009-12-02.

Maschler, Y. 1998. "On the transition from code-switching to a mixed code." In P. Auer (ed.), Code-Switching in Conversation. London: Routledge. 125-149.

McWhorter, John H. 2002. What happened to English? Diachronica 19:217-272.

McWhorter, John H. 2005. Dening creole. Oxford: Oxford University Press.

Muysken, P. 2000. Bilingual speech. A typology of code-switching. Oxford: Cambridge University Press.

Poplack, S. 1980. “Sometimes I'll start a sentence in Spanish y termino en español." Linguistics 18: 581-618. Poplack, S. 1981. Syntactic structure and social function. In R.P. Duran (ed.), Latino language and communicative behavior. Norwood, N.J.: Ablex. 169-84.

Sahgal, G. 2011. "New actors in English Vinglish”. The Indian Express. Retrieved 1 January 2012. http://www.glamsham.com/music/lyrics/lagaan/o-rey-chhori/99/2563.html

http://www.lyricsmaya.com/2016/10/breakup-song-lyrics-adhm.html http://www.lyricsmint.com/2012/08/english-vinglish-title-song-lyrics.html http://www.glamsham.com/music/lyrics/jab-we-met/tum-se-hi-romantic-love-songs-forvalentines-day-2015/681/1276.html

http://www.indicine.com/movies/bollywood/ranaji-lyrics-gulaal/ http://www.lyricsted.com/heer-toh-badi-sad-hai-lyrics-tamasha/\#ixzz4scy5PjKp http://www.exchange4media.com/advertising/airtel-brings-back-har-ek-friend-zaroorihota-hain-campaign-to-promote-new-product-features_66925.html 